\title{
Marital Satisfaction and a Sense of Life's Meaning Among Couples Struggling with Infertility. A Theological-Pastoral Take
}

\author{
JACEK GOLEŃ \\ The John Paul II Catholic University of Lublin \\ jacek.golen@kul.pl, ORCID: 0000-0001-9724-6936
}

\begin{abstract}
The problem of infertility today constitutes a challenge for pastoral theology and pastoral care of families. This article, of a theological-empirical character, addresses the correlation between marital satisfaction and a sense of life's meaning among infertile married couples who seek help in Catholic clinics for infertility treatment. It first discusses the theoretical background and selected results of existing scholarship on the influence that infertility has on conjugal relations and a sense of life's meaning. Then, it outlines the group of infertile married individuals studied and elucidates the research methodology employed. Then, the results of the research into a sense of life's meaning and marital satisfaction are presented, together with the correlation between the two factors. The final section of the article offers conclusions drawn from the research conducted. The article argues that a sense of life's meaning is visibly contingent on the respondents' martial satisfaction, especially on their working together on their problems and leading trustful conversations about them, on their care for strengthening their mutual love, and on showing the spouse that they are loved. On this basis, the article argues that pastoral care offered to infertile couples needs to enhance their faith, which will have a positive impact on their sense of life's meaning and on their marital satisfaction. Both within regular work at clinics for infertility diagnosis and treatment and within pastoral care, infertile couples should be taught to show care for their mutual bond, especially to have conversations that will enable them to manifest and strengthen their love and solve problems, as this would foster their marital satisfaction and enhance their sense of life's meaning.
\end{abstract}

Keywords: infertility, infertile couples, marital satisfaction, a sense of life's meaning, pastoral care of married couples

It is estimated that approximately one-fourth of the world's population struggles with the problem of infertility, while in Poland over 20 percent of couples are infertile. ${ }^{1}$ This means that numerous married couples experience the pain of physical infertility for a variety of reasons. ${ }^{2}$ Because of this, the problem may be treated as one of the challenges of the pastoral care offered by the Church to married couples and families.

The project is funded by the Minister of Science and Higher Education within the program under the name "Regional Initiative of Excellence" in 2019-2022, project number: 028/RID/2018/19, the amount of funding: 11742500 PLN.

1 Cf. Bielawska-Batorowicz, Trudności w realizacji planów prokreacyjnych, 415-416.

2 Cf. Francis, Amoris Laetitia, 180. 
The experience of infertility deeply affects and engages both women and men. Apart from the challenges of medical treatment, infertility implies psychic, social, and spiritual consequences, somewhat different for the two sexes. It has an impact on individuals and their attitudes to themselves and on their relations with their spouses and other people. ${ }^{3}$ For the believers, infertility affects as well their relationship with God and raises questions concerning the realization of marital duties and the sense of this difficult experience. ${ }^{4}$ Hence, it poses demanding tasks for the pastoral care of families.

In light of the above, it seems reasonable within the context of pastoral theology and its subdiscipline - pastoral care of families - to empirically examine mutual connections between infertility and marital satisfaction and a sense of life's meaning. Such a study would enable a formulation of pastoral conclusions to better understand individuals and couples struggling with infertility and to adequately plan and execute supporting pastoral care for them.

\section{The Impact of Infertility on Conjugal Relations and a Sense of Life's Meaning}

The experience of infertility has an impact on the psychic and spiritual life of women and men. It is an especially difficult experience for women, for whom their self-esteem is frequently linked with motherhood. They evince difficulties with self-acceptance, a sense of stigmatization, and frustration on the social, psychological, and existential planes. ${ }^{5}$ Frequently they fear the destabilization of their marriages and divorce, together with violence from the husband, family and community. ${ }^{6}$ They may experience their own helplessness and powerlessness, resentment, frustration, a sense of responsibility and injustice, and also a negative attitude to their own bodies and gender. For this reason, they may be overly sensitive to all stimuli from their environment pertaining to this sphere, may experience disorders of social interaction, and may show a tendency to interpret reality through the prism of the experienced problem. Painful feelings may be generated especially through contact with people and situations connected with maternity or fertility. ${ }^{7}$ Research shows that circa 24 to 36 percent of infertile women suffer depression, while 67 to 84 percent anxiety. Women who receive sufficient support from their close ones tend not to

\footnotetext{
Cf. Miernik, "Mężczyzna wobec niepowodzeń prokreacyjnych," 95.

Goleń - Kobak, Pastoral Care for Families, 402.

Cf. Kalus, Bezdzietność w małżenstwie, 25; Waroński, "Niepłodność," 400.

Cf. Dolińska, Bezdzietność, 150.

Cf. Orzeszyna, Teologiczno-moralny aspekt niepłodności, 18.
} 
suffer depression. ${ }^{8}$ Infertile men, in turn, tend to compensate for their frustration through various social achievements or successes that accentuate their masculinity and attractiveness. Lack of offspring has a negative impact on their perception of themselves, their wives, and marriages. They painfully feel powerlessness and guilt, especially when they are sure that the reason for infertility lies on their part. ${ }^{9}$ Diagnosis of infertility makes men reluctant to admit the problem and to express their feelings related to diagnosis and the proposed treatment. Men's feelings are as profound as women's, regardless of the reason for infertility. Similarly to women, they expect emotional support from their spouses. ${ }^{10}$

Infertility affects - and frequently constitutes a serious test for - the marital bond. This happens especially when a fertile partner manifests frustration or aggressive tendencies towards the infertile one. ${ }^{11}$ Even temporary infertility may leave its mark on conjugal and family relations, as parents who eventually have a child after going through exhausting medical procedures and a long period of waiting may become obsessively focused on the realization of their parenthood, which results in immature attitudes toward the child and the dysfunction of the relations with the spouse. ${ }^{12}$ Essentially, there are two different opinions on the way infertility affects marital relations. The first posits that involuntary childlessness leads to the deterioration of the marital bond and, thereby, marital satisfaction. The other maintains that the experience of infertility strengthens the marital bond and improves the functioning of the marital dyad. ${ }^{13}$ Some scholars claim that infertile spouses are characterized by a high level of adaptation to each other, lack of conflicts, and a very strong emotional bond. ${ }^{14}$ It seems that the consolidation of the ties between the partners - also in the case of infertility - may occur in couples that share religious values, for it has been proved that such compatibility correlates with marital satisfaction. ${ }^{15}$ The bond may be strengthened among couples that have already experienced emotional reactions typical of the "grieving the loss" phase and now undergo the phase of the socalled post-traumatic growth that brings positive changes in terms of their attitudes to life, self-perception and interpersonal relationships. ${ }^{16}$ It is at this point that couples often try to come to terms with the problem and that their sense of life's meaning increases. ${ }^{17}$ On the basis of their patients' statements, specialists working with infertile

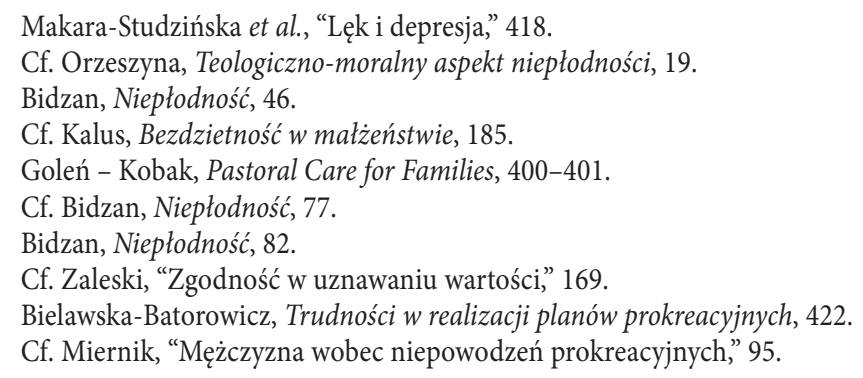


couples confirm that they may find a deeper sense in their infertility, seeing the fact as a way to conscious parenthood and spiritual development. ${ }^{18}$

Psychological research also points to the links between marital satisfaction and a sense of life's meaning. Marital satisfaction affects a person's functioning in all the individual and social spheres. Marital satisfaction is defined as a situation in which both partners feel happy and self-satisfied. It is a factor that enhances a sense of meaning and happiness in both of the spouses. At the same time it is obvious that achievement of satisfaction is a process that occurs throughout the life the spouses lead together and that requires an understanding of one's own preferences, a knowledge of one's own personality traits, an establishment of rules of behavior, and a respect for proper patterns of interpersonal communication and conflict solving. ${ }^{19}$

In light of the above, it seems that religiosity and positive attitudes to faith may enhance the spouses' sense of life's meaning and purpose also in situations of infertility. Working together on the problems related to infertility may eliminate disappointment, sustain and enhance marital satisfaction, and even lead to its increase. For this reason, Catholic clinics for infertility diagnosis and treatment propose a program based on NaProTechnology, whose crucial element is the couple's work on their mutual relation in the spiritual, physical, intellectual, creative, and emotional spheres (hence the name of the instruction - SPICE - as the acronym). ${ }^{20}$

For this reason, it is fully legitimate that a theological-empirical study of infertile couples should focus at the same time on the level of marital satisfaction and a sense of meaning and their mutual correlations.

\section{The Respondent Group and Research Methodology}

The study was conducted in Poland in 2018. It encompassed a group of 462 married individuals finding it difficult to conceive a child that were patients of Catholic clinics for infertility diagnosis and treatment. Among the respondents, there were 295 women (63,9 percent) and 167 men (36,1 percent). Slightly over half of the respondents $(52,16$ percent) were under 35 , with 47,84 percent - over 35 years of age. The level and type of education varied: there were people with primary, vocational, and secondary education (altogether they comprised 21,65 percent) and higher education (78,36 percent). Among the second group, the majority majored in sciences (40,48 percent), while those with diplomas in the humanities comprised 37,88 percent. The vast majority of the respondents ( 88,1 percent) grew up in com-

\footnotetext{
18 Cf. Dembińska, "Rola nadziei," 17; Dimech-Juchniewicz, Facing Infertility, 151.

19 Cf. Krok, "Satysfakcja ze związku małżeńskiego," 142-147.

20 Cf. Hilgers et al., The Creighton Model FertilityCare System, 231-234.
} 
plete family units, with only 11,9 percent raised in single-parent families, permanently - for a number of reasons such as death or divorce - or temporarily. As many as 91,99 percent of those surveyed had siblings. Among these, the majority had one brother or sister (37,88 percent), 28,14 percent had two siblings, and 25,97 percent - three or more. As far as attitude to faith is concerned, 76,62 percent of the respondents declared themselves to be strong believers and active practitioners, while the remaining 23,38 percent classified themselves as weak believers or seldom practicing believers (see Table 1 ).

Table 1. Socio-demographic features of the respondents.

\begin{tabular}{|c|c|c|c|}
\hline Variable & Group & $\mathrm{N}$ group & $\%$ group \\
\hline \multirow[t]{3}{*}{ Sex } & Women & 295 & 63,90 \\
\hline & Men & 167 & 36,10 \\
\hline & Altogether & 462 & 100,00 \\
\hline \multirow[t]{3}{*}{ Age } & Under 35 & 241 & 52,16 \\
\hline & Over 35 & 221 & 47,84 \\
\hline & Altogether & 462 & 100,00 \\
\hline \multirow[t]{4}{*}{ Education } & Primary/vocational/secondary & 100 & 21,65 \\
\hline & Higher (humanities) & 175 & 37,88 \\
\hline & Higher (sciences) & 187 & 40,48 \\
\hline & Altogether & 462 & 100,00 \\
\hline \multirow[t]{3}{*}{ Natal family } & Complete (with both parents) & 407 & 88,10 \\
\hline & Single-parent & 55 & 11,90 \\
\hline & Altogether & 462 & 100,00 \\
\hline \multirow[t]{5}{*}{ Number of siblings } & None & 37 & 8,01 \\
\hline & One & 175 & 37,88 \\
\hline & Two & 130 & 28,14 \\
\hline & Three or more & 120 & 25,97 \\
\hline & Altogether & 462 & 100,00 \\
\hline \multirow[t]{3}{*}{ Attitude to faith } & $\mathrm{SPB} / \mathrm{WB}$ & 108 & 23,38 \\
\hline & SBAP & 354 & 76,62 \\
\hline & Altogether & 462 & 100,00 \\
\hline
\end{tabular}

Abbreviations: SBAP - strong believer and active practitioner, SPB - seldom practicing believer, WB - weak believer. 
A research tool employed to study the sense of life's meaning was the MLQ questionnaire (Meaning in Life Questionnaire), ${ }^{21}$ in its Polish version translated by Michał Wiechetek from the Catholic University of Lublin. The questionnaire comprises 10 questions (see Table 2). The respondents were to express their opinions on given statements by deciding if they agree or disagree with them on a scale from 1 to 7 , where the lowest number indicated complete lack of acceptance, and the highest - total acceptance of the statement ( 1 - absolutely untrue, 2 - mostly untrue, 3 - somewhat untrue, 4 - can't say true or false, 5 - somewhat true, 6 - mostly true, 7 - absolutely true). On the basis of the answers, average values were calculated to describe the level of acceptance of a given statement on the same scale of 1-7.

My own questionnaire of 12 questions was used to assess the subjective level of marital satisfaction (see Table 4). To evaluate the validity of the tool and its internal coherence, Cronbach's alpha was calculated. It amounted to 0,636 , which shows that the test complied with the requirements of internal coherence and reliability. Average covariance between items numbered 0,160 . The respondents were to react to given statements by deciding if they agree or disagree with them on a scale from 0 to 5 , where the lowest number corresponded to total lack of acceptance, while the highest indicated complete agreement ( 0 - totally disagree, 1 - disagree, 2 - agree to a small extent, 3 agree to a large extent, 4 - agree, 5 - totally agree). Average values were calculated on the basis of the answers given using the same scale of $0-5$. To analyze the results, statistical tests of Shapiro-Wilk, Mann-Whitney and Kruskal-Wallis were used. ${ }^{22}$ Spearman's rank correlation coefficient was calculated to analyze correlations between variables. Differences in values were deemed statistically important when the value of $\mathrm{p}<0,05$.

\section{The Respondents' Sense of Life's Meaning and Purpose}

Previous research suggests that the problem of infertility may have an impact on the spouses' subjective opinions and a sense of life's meaning and purpose. For this reason, my study investigated how the respondents perceive the meaning and purpose of their lives. The results of the survey show that the most accepted statement was "I understand my life's meaning" The mean value of the frequency of its selection was $5,82 \pm 1,22$, and the median $-6,0$. This means that the respondents agreed with this statement to a large extent. The statement "My life has a clear sense of purpose" received similar responses $(\mathrm{M}=5,44 \pm 1,56 ; \mathrm{Me}=6,0)$. The least accepted statement was: "My life has no clear purpose." The mean value for the frequency with which the

21 See Steger et al., "The Meaning in Life Questionnaire," 80-93.

22 Cf. Frankfort-Nachmias - Nachmias, Metody badawcze w naukach społecznych, 507-508; Francuz Mackiewicz, Liczby nie wiedza, skąd pochodzą, 435-436, 449-450. 
statement was chosen was $2,10 \pm 1,55$, and the median of acceptance amounted to 7,0. This means that the respondents disagreed with the statement. The statement "I am always looking to find my life's purpose" achieved similar results, with the mean value of $3,61 \pm 1,88$, and the median of 3,0 . In other words, the respondents rather disagreed with the statement. A similarly low result was achieved by the statement "I am seeking a purpose or mission for my life" $(\mathrm{M}=3,78 \pm 2,13 ; \mathrm{Me}=4,0)$. The results show that the respondents to a large extent agree that they see meaning and purpose in their lives, and they disagree that their lives have no clear aim and moderately disagree that they are only now seeking the meaning and purpose of life (see Table 2).

Table 2. The respondents' opinions on the meaning and purpose of life in numbers and percentages.

\begin{tabular}{|c|c|c|c|c|c|c|c|c|c|c|c|}
\hline \multicolumn{2}{|l|}{$\begin{array}{l}\text { Evaluation } \\
\text { of the meaning of life }\end{array}$} & 1 & 2 & 3 & 4 & 5 & 6 & 7 & $\mathbf{M}$ & SD & $\mathrm{Me}$ \\
\hline \multirow{2}{*}{$\begin{array}{l}\text { I understand } \\
\text { my life's meaning }\end{array}$} & $\mathrm{n}$ & 4 & 3 & 11 & 45 & 100 & 126 & 173 & \multirow{2}{*}{5,82} & \multirow{2}{*}{1,22} & \multirow{2}{*}{6,0} \\
\hline & $\%$ & 0,87 & 0,65 & 2,38 & 9,74 & 21,65 & 27,27 & 37,45 & & & \\
\hline \multirow{2}{*}{$\begin{array}{l}\text { I am looking for } \\
\text { something that makes } \\
\text { my life feel meaningful }\end{array}$} & $\mathrm{n}$ & 35 & 44 & 57 & 45 & 94 & 92 & 95 & \multirow{2}{*}{4,68} & \multirow{2}{*}{1,89} & \multirow[b]{2}{*}{5,0} \\
\hline & $\%$ & 7,58 & 9,52 & 12,34 & 9,74 & 20,35 & 19,91 & 20,56 & & & \\
\hline \multirow{2}{*}{$\begin{array}{l}\text { I am always looking } \\
\text { to find my life's purpose }\end{array}$} & $\mathrm{n}$ & 74 & 82 & 90 & 46 & 80 & 55 & 35 & \multirow{2}{*}{3,61} & \multirow{2}{*}{1,88} & \multirow{2}{*}{3,0} \\
\hline & $\%$ & 16,02 & 17,75 & 19,48 & 9,96 & 17,32 & 11,90 & 7,58 & & & \\
\hline \multirow{2}{*}{$\begin{array}{l}\text { My life has a clear sense } \\
\text { of purpose }\end{array}$} & $\mathrm{n}$ & 7 & 18 & 45 & 40 & 88 & 112 & 152 & \multirow{2}{*}{5,44} & \multirow{2}{*}{1,56} & \multirow{2}{*}{6,0} \\
\hline & $\%$ & 1,52 & 3,90 & 9,74 & 8,66 & 19,05 & 24,24 & 32,90 & & & \\
\hline \multirow{2}{*}{$\begin{array}{l}\text { I have a good sense } \\
\text { of what makes my life } \\
\text { meaningful }\end{array}$} & $\mathrm{n}$ & 8 & 18 & 30 & 54 & 99 & 126 & 127 & \multirow{2}{*}{5,39} & \multirow{2}{*}{1,49} & \multirow{2}{*}{6,0} \\
\hline & $\%$ & 1,73 & 3,90 & 6,49 & 11,69 & 21,43 & 27,27 & 27,49 & & & \\
\hline \multirow{2}{*}{$\begin{array}{l}\text { I have discovered } \\
\text { a satisfying life purpose }\end{array}$} & $\mathrm{n}$ & 8 & 19 & 35 & 55 & 88 & 122 & 135 & \multirow{2}{*}{5,39} & \multirow{2}{*}{1,53} & \multirow{2}{*}{6,0} \\
\hline & $\%$ & 1,73 & 4,11 & 7,58 & 11,90 & 19,05 & 26,41 & 29,22 & & & \\
\hline \multirow{2}{*}{$\begin{array}{l}\text { I am always searching for } \\
\text { something that makes } \\
\text { my life feel significant }\end{array}$} & $\mathrm{n}$ & 11 & 25 & 22 & 49 & 122 & 121 & 112 & \multirow{2}{*}{5,29} & \multirow{2}{*}{1,52} & \multirow{2}{*}{6,0} \\
\hline & $\%$ & 2,38 & 5,41 & 4,76 & 10,61 & 26,41 & 26,19 & 24,24 & & & \\
\hline \multirow{2}{*}{$\begin{array}{l}\text { I am seeking a purpose } \\
\text { or mission for my life }\end{array}$} & $\mathrm{n}$ & 34 & 51 & 67 & 56 & 88 & 103 & 63 & \multirow{2}{*}{4,46} & \multirow{2}{*}{1,83} & \multirow{2}{*}{5,0} \\
\hline & $\%$ & 7,36 & 11,04 & 14,50 & 12,12 & 19,05 & 22,29 & 13,64 & & & \\
\hline My life has no clear & $\mathrm{n}$ & 11 & 11 & 26 & 31 & 52 & 84 & 247 & 40 & 155 & 70 \\
\hline purpose & $\%$ & 2,38 & 2,38 & 5,63 & 6,71 & 11,26 & 18,18 & 53,46 & 4,90 & | &,, 0 \\
\hline I am searching for & $\mathrm{n}$ & 99 & 73 & 44 & 49 & 69 & 67 & 61 & 378 & 213 & 40 \\
\hline meaning in my life & $\%$ & 21,43 & 15,80 & 9,52 & 10,61 & 14,94 & 14,50 & 13,20 & ס & $\mid 2,15$ & 4,0 \\
\hline
\end{tabular}

Abbreviations: $\mathrm{M}$ - mean; SD - standard deviation; Me - median. Possible answers:

1 - absolutely untrue, 2 - mostly untrue, 3 - somewhat untrue, 4 - can't say true or false,

5 - somewhat true, 6 - mostly true, 7 - absolutely true. 
The values showing how the respondents perceive the sense and purpose of life were also analyzed with respect to selected socio-demographic factors. The impact of variables such as sex, age, education, attitude to faith, natal family, and number of siblings is shown in Table 3.

Table 3. Single-factor statistical analysis of the overall assessment of the respondents' sense and purpose of life and the impact of socio-demographic factors.

\begin{tabular}{|c|c|c|c|c|c|c|}
\hline Group & M & SD & $\mathrm{Me}$ & dM & Test result & p \\
\hline \multicolumn{7}{|c|}{ Sex } \\
\hline Women & 70,6 & 11,4 & 70,0 & \multirow{2}{*}{$-1,35$} & \multirow{2}{*}{$-1,538^{\mathrm{z}}$} & \multirow{2}{*}{0,124} \\
\hline Men & 71,9 & 9,8 & 72,9 & & & \\
\hline \multicolumn{7}{|c|}{ Age } \\
\hline Over 35 & 71,8 & 10,5 & 71,4 & \multirow{2}{*}{1,35} & \multirow{2}{*}{$1,236^{\mathrm{Z}}$} & \multirow{2}{*}{0,216} \\
\hline Under 35 & 70,4 & 11,2 & 70,0 & & & \\
\hline \multicolumn{7}{|c|}{ Education } \\
\hline Primary/vocational/secondary & 70,6 & 10,7 & 72,9 & \multirow{3}{*}{0,94} & \multirow{3}{*}{$0,483^{\mathrm{H}}$} & \multirow{3}{*}{0,786} \\
\hline Higher (humanities) & 71,6 & 11,5 & 71,4 & & & \\
\hline Higher (sciences) & 70,9 & 10,4 & 70,0 & & & \\
\hline \multicolumn{7}{|c|}{ Attitude to faith } \\
\hline SBAP & 70,9 & 11,1 & 70,0 & \multirow{2}{*}{$-0,83$} & \multirow{2}{*}{$-0,843^{Z}$} & \multirow{2}{*}{0,399} \\
\hline $\mathrm{SPB} / \mathrm{WB}$ & 71,7 & 10,2 & 71,4 & & & \\
\hline \multicolumn{7}{|c|}{ Natal family } \\
\hline Complete & 70,9 & 11,1 & 70,0 & \multirow{2}{*}{$-1,31$} & \multirow{2}{*}{$-1,106^{\mathrm{Z}}$} & \multirow{2}{*}{0,269} \\
\hline Single-parent & 72,2 & 9,2 & 72,9 & & & \\
\hline \multicolumn{7}{|c|}{ Number of siblings } \\
\hline None & 71,1 & 10,6 & 71,4 & \multirow{4}{*}{2,16} & \multirow{4}{*}{$3,646^{\mathrm{H}}$} & \multirow{4}{*}{0,302} \\
\hline One & 70,1 & 10,0 & 68,6 & & & \\
\hline Two & 72,3 & 11,4 & 72,9 & & & \\
\hline Three or more & 71,1 & 11,6 & 70,0 & & & \\
\hline
\end{tabular}

Abbreviations: $\mathrm{M}$ - mean; SD - standard deviation; Me - median; $\mathrm{dM}$ - difference between means; $\mathrm{Z}$ - Mann-Whitney test result; $\mathrm{H}$ - Kruskal-Wallis test result; $\mathrm{p}$ - significance level; SBAP - strong believer and active practitioner; SPB - seldom practicing believer; WB - weak believer. 
The results included in Table 3 show that none of the independent variables has a statistically important impact on the way the respondents perceive the sense and purpose of their lives $(p>0,05)$. This means that similar results were achieved in all subgroups of respondents.

\section{Marital Satisfaction in Infertile Couples}

Among the statements concerning the level of marital satisfaction in situations of infertility the most accepted one was: "I fully accept my spouse despite the fact we cannot conceive a child" and "I feel loved by my spouse." The mean value for the two statements calculated on the basis of the frequency of the answers given was 4,59, and the median of the level of acceptance was 5,0. Similarly high results were achieved by the statements "Our marriage is happy" $(\mathrm{M}=4,39 ; \mathrm{Me}=5,0)$ and "Me and my spouse understand each other" $(M=4,30 ; M e=5,0)$. Such results indicate that the respondents fully agreed with these statements. By contrast, the least accepted statement was: "I feel resentment toward my spouse because we cannot conceive a child." The mean value of the frequency was $0,55 \pm 1,12$, and the median of the acceptance of this statement was 0,0 . This means that the respondents decidedly disagreed with the statement (see Table 4).

Table 4. Opinions on marital satisfaction in numbers and percentages.

\begin{tabular}{|c|c|c|c|c|c|c|c|c|c|c|}
\hline \multicolumn{2}{|l|}{ Marital satisfaction } & 0 & 1 & 2 & 3 & 4 & 5 & M & SD & $\mathrm{Me}$ \\
\hline \multirow{2}{*}{$\begin{array}{l}\text { Mutual love is more important } \\
\text { in marriage than the ability } \\
\text { to conceive a child }\end{array}$} & $\mathrm{n}$ & 6 & 6 & 35 & 81 & 126 & 208 & \multirow{2}{*}{4,03} & \multirow{2}{*}{1,12} & \multirow{2}{*}{4,0} \\
\hline & $\%$ & 1,30 & 1,30 & 7,58 & 17,53 & 27,27 & 45,02 & & & \\
\hline \multirow{2}{*}{$\begin{array}{l}\text { Me and my spouse understand } \\
\text { each other }\end{array}$} & $\mathrm{n}$ & 2 & 1 & 19 & 68 & 117 & 255 & \multirow{2}{*}{4,30} & \multirow{2}{*}{0,93} & \multirow{2}{*}{5,0} \\
\hline & $\%$ & 0,43 & 0,22 & 4,11 & 14,72 & 25,32 & 55,19 & & & \\
\hline \multirow{2}{*}{$\begin{array}{l}\text { I feel sorry for my spouse } \\
\text { on account of our difficulties } \\
\text { to conceive }\end{array}$} & $\mathrm{n}$ & 8 & 14 & 26 & 71 & 138 & 205 & \multirow{2}{*}{4,02} & \multirow{2}{*}{1,17} & \multirow{2}{*}{4,0} \\
\hline & $\%$ & 1,73 & 3,03 & 5,63 & 15,37 & 29,87 & 44,37 & & & \\
\hline \multirow{2}{*}{$\begin{array}{l}\text { I trustfully talk to my spouse } \\
\text { about our infertility problem }\end{array}$} & $\mathrm{n}$ & 3 & 7 & 25 & 46 & 120 & 261 & \multirow{2}{*}{4,29} & \multirow{2}{*}{1,02} & \multirow{2}{*}{5,0} \\
\hline & $\%$ & 0,65 & 1,52 & 5,41 & 9,96 & 25,97 & 56,49 & & & \\
\hline \multirow{2}{*}{$\begin{array}{l}\text { Infertility strengthens } \\
\text { our mutual love }\end{array}$} & $\mathrm{n}$ & 12 & 26 & 70 & 85 & 115 & 154 & \multirow{2}{*}{3,57} & \multirow{2}{*}{1,37} & \multirow{2}{*}{4,0} \\
\hline & $\%$ & 2,60 & 5,63 & 15,15 & 18,40 & 24,89 & 33,33 & & & \\
\hline \multirow{2}{*}{$\begin{array}{l}\text { I fully accept my spouse } \\
\text { despite the fact we cannot } \\
\text { conceive a child }\end{array}$} & $\mathrm{n}$ & 1 & 1 & 10 & 34 & 83 & 333 & \multirow{2}{*}{4,59} & \multirow{2}{*}{0,77} & \multirow{2}{*}{5,0} \\
\hline & $\%$ & 0,22 & 0,22 & 2,16 & 7,36 & 17,97 & 72,08 & & & \\
\hline
\end{tabular}


JACEK GOLEŃ

\begin{tabular}{|c|c|c|c|c|c|c|c|c|c|c|}
\hline \multicolumn{2}{|l|}{ Marital satisfaction } & 0 & 1 & 2 & 3 & 4 & 5 & M & SD & Me \\
\hline \multirow{2}{*}{$\begin{array}{l}\text { I feel resentment toward } \\
\text { my spouse because we cannot } \\
\text { conceive a child }\end{array}$} & $\mathrm{n}$ & 332 & 75 & 18 & 17 & 9 & 11 & \multirow{2}{*}{0,55} & \multirow{2}{*}{1,12} & \multirow{2}{*}{0,0} \\
\hline & $\%$ & 71,86 & 16,23 & 3,90 & 3,68 & 1,95 & 2,38 & & & \\
\hline \multirow{2}{*}{$\begin{array}{l}\text { Infertility leads to the } \\
\text { deterioration of our marital } \\
\text { bond }\end{array}$} & $\mathrm{n}$ & 230 & 112 & 40 & 29 & 36 & 15 & \multirow{2}{*}{1,08} & \multirow{2}{*}{1,43} & \multirow{2}{*}{1,0} \\
\hline & $\%$ & 49,78 & 24,24 & 8,66 & 6,28 & 7,79 & 3,25 & & & \\
\hline \multirow{2}{*}{$\begin{array}{l}\text { We both accept potential } \\
\text { adoption }\end{array}$} & $\mathrm{n}$ & 33 & 60 & 111 & 80 & 60 & 118 & \multirow{2}{*}{2,93} & \multirow{2}{*}{1,60} & \multirow{2}{*}{3,0} \\
\hline & $\%$ & 7,14 & 12,99 & 24,03 & 17,32 & 12,99 & 25,54 & & & \\
\hline \multirow{2}{*}{$\begin{array}{l}\text { We are both engaged } \\
\text { in the diagnosis and treatment } \\
\text { of infertility }\end{array}$} & $\mathrm{n}$ & 6 & 14 & 37 & 74 & 112 & 219 & \multirow{2}{*}{4,01} & \multirow{2}{*}{1,20} & \multirow{2}{*}{4,0} \\
\hline & $\%$ & 1,30 & 3,03 & 8,01 & 16,02 & 24,24 & 47,40 & & & \\
\hline \multirow[t]{2}{*}{ Our marriage is happy } & $\mathrm{n}$ & 1 & 7 & 9 & 59 & 105 & 281 & \multirow{2}{*}{4,39} & \multirow{2}{*}{0,91} & \multirow{2}{*}{5,0} \\
\hline & $\%$ & 0,22 & 1,52 & 1,95 & 12,77 & 22,73 & 60,82 & & & \\
\hline \multirow[t]{2}{*}{ I feel loved by my spouse } & $\mathrm{n}$ & 1 & 5 & 13 & 22 & 80 & 341 & \multirow{2}{*}{4,59} & \multirow{2}{*}{0,82} & \multirow{2}{*}{5,0} \\
\hline & $\%$ & 0,22 & 1,08 & 2,81 & 4,76 & 17,32 & 73,81 & & & \\
\hline
\end{tabular}

Abbreviations: M - mean; SD - standard deviation; Me - median; possible answers: 0 - totally disagree, 1 - disagree, 2 - agree to a small extent, 3 - agree to a large extent, 4 - agree, 5 - totally agree.

The results show that infertility does not have a substantial bearing on the couples' sense of marital satisfaction. These results can possibly be linked to the couples' compatibility with respect to religious values and faith (they declare themselves to be believers and seek help in Catholic clinics for infertility diagnosis and treatment), which helps them in going through subsequent stages of "grieving the loss." What is more, the programs of regular spiritual and psychological work on the marital bond that are deployed in Catholic clinics clearly seem to bring about the desired results. Still, over 17 percent of the respondents admit that to some extent infertility leads to the deterioration of their marital bond (see Table 4). This value shows the necessity of the pastoral care of infertile couples, especially in the initial stages of their grieving. This could strengthen their faith and offer additional support, thereby enhancing their marital satisfaction.

\section{Assessment of Life's Meaning and Purpose and Marital Satisfaction}

My study probed the connections between survey results concerning the respondents' assessment of the meaning and purpose of life and the results showing the level of marital satisfaction. The analysis of data correlation was carried out with the use of Spearman's rank correlation test. Statistically important dependency $(p<0,05)$ 
occurred in the case of 5 statements concerning the level of marital satisfaction, namely: "I trustfully talk to my spouse about our infertility problem," "Infertility strengthens our mutual love," "We both accept potential adoption," "Our marriage is happy," "I feel loved by my spouse." For all the five statements the correlation coefficient was positive $(\mathrm{R}>0)$, which testifies to the directly proportional contingency; in other words, the higher the assessment of life's meaning and purpose, the more the respondents agree with the above statements, or the other way round, the more content they are with their marriages, the stronger their sense of meaning and purpose. The latter interpretation seems more probable, namely that marital satisfaction constitutes one of the bases of a sense of life's meaning and purpose. Detailed data on the correlation analysis is presented in Table 5.

Table 5. Correlation coefficients between overall assessment of life's meaning and purpose and the level of acceptance of statements concerning marital satisfaction.

\begin{tabular}{|l|c|c|c|}
\hline \multicolumn{1}{|c|}{ Overall assessment of life's meaning vs. } & R & t(N-2) & p \\
\hline Mutual love is more important in marriage than the ability to conceive a child & 0,063 & 1,349 & 0,178 \\
\hline Me and my spouse understand each other & 0,083 & 1,776 & 0,076 \\
\hline I feel sorry for my spouse on account of our difficulties to conceive & 0,034 & 0,736 & 0,462 \\
\hline I trustfully talk to my spouse about our infertility problem & 0,115 & 2,494 & 0,013 \\
\hline Infertility strengthens our mutual love & 0,146 & 3,166 & 0,002 \\
\hline I fully accept my spouse despite the fact we cannot conceive a child & 0,051 & 1,092 & 0,275 \\
\hline I feel resentment toward my spouse because we cannot conceive a child & 0,030 & 0,647 & 0,518 \\
\hline Infertility leads to the deterioration of our marital bond & $-0,023$ & $-0,499$ & 0,618 \\
\hline We both accept potential adoption & 0,144 & 3,111 & 0,002 \\
\hline We are both engaged in the diagnosis and treatment of infertility & 0,052 & 1,124 & 0,262 \\
\hline Our marriage is happy & 0,099 & 2,124 & 0,034 \\
\hline I feel loved by my spouse & 0,116 & 2,511 & 0,012 \\
\hline
\end{tabular}

Abbreviations: $\mathrm{R}$ - correlation coefficient between variables, $\mathrm{t}(\mathrm{N}-2)$ - Spearman's rank correlation test result, $\mathrm{p}$ - the correlation coefficient's significance level.

My statistical analysis also scrutinized the links between the overall assessment of life's meaning and purpose and the levels of the respondents' marital satisfaction, taking into account also their attitude to faith. The analysis of data correlation was conducted with the use of Spearman's rank correlation test. Statistically relevant contingency $(p>0,05)$ was noted in the case of 4 statements concerning the level of mar- 
ital satisfaction: "Me and my spouse understand each other," "Infertility strengthens our mutual love," "Our marriage is happy," "I feel loved by my spouse." The correlation coefficient for these statements was positive $(R>0)$, which testifies to the directly proportional dependency: the higher the assessment of life's meaning and purpose, the more the respondents agree with the above statements, or the other way round, the more content they are with their marriages, the stronger their sense of life's meaning and purpose. Among seldom practicing believers and weak believers, the coefficient $\mathrm{R}$ was significantly higher than for strong believers and active practitioners. This means that for seldom practicing believers and weak believers marital satisfaction correlates more strongly with a sense of life's meaning and purpose than for those who are strong believers and active practitioners. It seems that due to the weaker faith of this group of respondents, their sense of life's meaning and purpose lacks additional foundations and is to a larger degree linked to marital satisfaction and its individual reflections. In case of some deficits in marital and family life, such people may be more likely to lose their sense of life's meaning and purpose, which in turn may more strongly encumber their marriages. Detailed data on the analysis of correlations is presented in Table 6 .

Table 6. Correlation coefficients between an overall assessment of life's meaning and the level of marital satisfaction, taking into account the respondents' attitude to faith.

\begin{tabular}{|l|c|c|c|c|c|c|}
\hline \multirow{2}{*}{$\begin{array}{c}\text { The two variables - } \\
\text { Overall assessment of life's meaning vs. }\end{array}$} & \multicolumn{3}{|c|}{ SBAP } & \multicolumn{3}{c|}{ SPB/WB } \\
\cline { 2 - 8 } & $\mathbf{R}$ & $\mathbf{t}(\mathbf{N}-2)$ & $\mathbf{p}$ & $\mathbf{R}$ & $\mathbf{t}(\mathrm{N}-2)$ & $\mathbf{p}$ \\
\hline Me and my spouse understand each other & 0,123 & 2,320 & 0,021 & 0,330 & 3,598 & $<0,001$ \\
\hline Infertility strengthens our mutual love & 0,173 & 3,292 & 0,001 & 0,326 & 3,554 & 0,001 \\
\hline Our marriage is happy & 0,099 & 1,873 & 0,062 & 0,504 & 6,004 & $<0,001$ \\
\hline I feel loved by my spouse & 0,142 & 2,691 & 0,007 & 0,458 & 5,302 & $<0,001$ \\
\hline
\end{tabular}

Abbreviations: $\mathrm{R}$ - the correlation coefficient between variables, $\mathrm{t}(\mathrm{N}-2)$ - Spearman's rank correlation test result, $\mathrm{p}$ - the correlation coefficient's significance level.

My statistical analysis also probed the connections between the results of the overall assessment of life's meaning and purpose and the respondents' marital satisfaction, taking into account the natal family of the respondents. Data correlation was analyzed with the use of Spearman's rank correlation test. The dependency was found to be statistically relevant $(p>0,05)$ for two statements concerning marital satisfaction, namely: "Me and my spouse understand each other" and "Infertility strengthens our mutual love." In both cases the correlation coefficient was positive $(\mathrm{R}>0)$, which indicates the directly proportional character of the dependency: the higher the re- 
spondents' assessment of their lives' meaning and purpose, the more likely they were to agree with the statements above, or the other way round.

It is worthy of note that for the respondents brought up in single-parent families, the coefficients $\mathrm{R}$ were noticeably higher than for those raised in complete family units. This suggests that for individuals coming from single-parent families a sense of life's meaning and purpose correlates more strongly with marital satisfaction than is the case for the respondents raised in complete families. A probable interpretation is that for the former marital satisfaction has a bearing on their sense of life's meaning and purpose. An experience of some deficits in marital/family life in the natal family may cause a stronger focus on this aspect of life and a stronger connection felt between the meaning of life and marital satisfaction and success. Detailed data on correlation analysis may be found in Table 7.

Table 7. Correlation coefficients between the overall assessment of life's meaning and marital satisfaction, taking into account the respondents' natal families.

\begin{tabular}{|l|c|c|c|c|c|c|}
\hline \multirow{2}{*}{$\begin{array}{c}\text { The two variables - } \\
\text { Overall assessment of life's meaning vs. }\end{array}$} & \multicolumn{3}{|c|}{ Complete family } & \multicolumn{3}{c|}{ Single-parent family } \\
\cline { 2 - 8 } & $\mathbf{R}$ & $\mathbf{t}(\mathbf{N}-\mathbf{2})$ & $\mathbf{p}$ & $\mathbf{R}$ & $\mathbf{t}(\mathbf{N}-2)$ & $\mathbf{p}$ \\
\hline Me and my spouse understand each other & 0,123 & 2,320 & 0,021 & 0,330 & 3,598 & $<0,001$ \\
\hline Infertility strengthens our mutual love & 0,173 & 3,292 & 0,001 & 0,326 & 3,554 & 0,001 \\
\hline
\end{tabular}

Abbreviations: $\mathrm{R}$ - the correlation coefficient between variables, $\mathrm{t}(\mathrm{N}-2)$ - Spearman's rank correlation test result, $\mathrm{p}$ - the correlation coefficient's significance level.

\section{Conclusions for the Pastoral Care of Infertile Couples}

The vast majority of the respondents showed a high sense of life's meaning and purpose. This may be related to the faith they declare and often practice that broadens their perspectives and offers support. Moreover, treatment at a Catholic clinic, where couples realize a program of enhancing their marital bond, may aid them in the difficult situation of infertility and foster their mutual understanding, compassion, trust, acceptance, a sense of happiness, conversations about the problem, and mutual engagement in treatment (see Table 4).

What is interesting is the correlation between the respondents' sense of life's meaning and purpose and their marital satisfaction. My research indicates that a sense of meaning has a positive correlation with marital satisfaction. It is especially the trustful conversations of the infertile couples about their problems, their care for strengthening their love, their mutual sense of marital happiness, and a sense 
of being loved by their spouse that have a substantial bearing on the sense of life's meaning and purpose in their situation of infertility. These result in the spouses' considerable acceptance of their situation, reflected among others in their mutual sense of marital happiness and approval of possible adoption (see Table 5). ${ }^{23}$ Such an interpretation is further corroborated by the fact that weak believers or seldom practicing believers evince a higher correlation between their sense of life's meaning and purpose and marital satisfaction than strong and actively practicing believers (see Table 6). This may suggest that those who do not find support in their faith and religious practices show a more clear dependence of their sense of life's meaning on marital satisfaction. By the same token, individuals raised in single-parent families, who have experienced deficits in marital-family life and often lack good models of marriage and family, show a strong connection between a sense of life's meaning and purpose with marital satisfaction. On account of their experiences, they may concentrate on making their own marriages successful and because of that they link their sense of life with marital success.

The conclusions drawn from the results of the research are as follows: 1) the vast majority of married individuals struggling with the problem of infertility and seeking treatment in Catholic clinics show a high sense of life's meaning and purpose; 2) marital satisfaction of infertile couples is contingent on their sense of life's meaning and purpose; 3) a sense of life's meaning and purpose for infertile couples treated in Catholic clinics is dependent on their marital satisfaction, especially on regular work on their marital bond (e.g. employment of the SPICE instruction), mutual support and engagement in working on their problems, leading conversations about their problems in the atmosphere of trust, care for strengthening their mutual love, and showing the spouse that they are loved; 4 ) a stronger correlation between a sense of life's meaning and purpose and marital satisfaction in situations of infertility occurs in couples that are weak believers or seldom practicing believers and those raised in single-parent families.

These research conclusions lead to the following suggestions for pastoral care: 1) it is worthwhile to offer pastoral care to couples finding it difficult to conceive as it can strengthen their faith and trust in God, which in turn will have a bearing on their sense of life's meaning and purpose, marital satisfaction, and the handling of problems related to infertility; 2) it is worthwhile to create, develop and promote among engaged and married couples Catholic clinics for infertility treatment that make use of NaProTechnology and that implement programs for working on the spouses' marital bond, e.g. the SPICE instruction; 3 ) while offering pastoral care to infertile couples and during professional work in the clinic, one needs to take into account the impact that marital satisfaction has on the patients' sense of life's meaning and purpose. This means that both clergymen and specialists working in the clinics need

23 See Dimech-Juchniewicz, Facing Infertility, 123-138. 
to support the couples in working on their problems, motivate them and offer them professional help in leading a dialogue based on trust, especially teaching the spouses to daily strengthen their bond; 4) such a support is more often needed by weak believers or seldom practicing believers and those raised in single-parent families.

The research results show a necessity for conducting a deeper theological-empirical research, especially as regards the impact that faith and religious practices have on one's sense of life's meaning and on one's engagement in working on the marital bond, as well as on an increase in levels of marital satisfaction, both for the general population and specifically for infertile couples. It also seems relevant to study the correlation between a sense of life's meaning and marital satisfaction among infertile couples separately for men and women.

\section{Bibliography}

Bidzan, M., Niepłodność w ujęciu bio-psycho-społecznym, 2 ed. (Kraków: Impuls 2010).

Bielawska-Batorowicz, E., "Trudności w realizacji planów prokreacyjnych i ich skutki dla rodziny," Psychologia rodziny (eds. I. Janicka - H. Liberska) (Warszawa: Wydawnictwo Naukowe PWN 2014) 411-436.

Dembińska, A., "Rola nadziei w pomocy psychologicznej kobietom leczącym niepłodność," Sztuka Leczenia 26/1-2 (2013) 9-20.

Dimech-Juchniewicz, J., Facing Infertility. A Catholic Approach (Boston, MA: Pauline Book and Media 2012).

Dolińska, B., Bezdzietność. Perspektywa społeczno-kulturowa (Sopot: Smak Słowa 2014).

Francis, Post-Synodal Apostolic Exhortation Amoris Laetitia (2016).

Francuz, P. - Mackiewicz, R., Liczby nie wiedza, skąd pochodza. Przewodnik po metodologii i statystyce (Lublin: Wydawnictwo KUL 2005).

Frankfort-Nachmias, C. - Nachmias, D., Metody badawcze w naukach społecznych (trans. E. Hornowska) (Poznań: Zysk i S-ka 2001).

Goleń, J. - Kobak, J., "Pastoral Care for Families Suffering from Infertility, Catholic Family Ministry. The Scientific Reflection and the Practical Ministry of the Church (eds. J. Golen R. Kamiński - G. Pyźlak) (Lublin: Wydawnictwo KUL 2018) 397-408.

Hilgers, T.W. et al., The Creighton Model FertilityCare System. I. Basic Teaching Skills, 2 ed. (Omaha, NE: Pope Paul VI Institute 2002).

Kalus, A., Bezdzietność w małżeństwie (Opole: Wydawnictwo UO 2002).

Krok, D., "Satysfakcja ze związku małżeńskiego a poziom hedonistycznego i eudajmonistycznego dobrostanu psychicznego małżonków," Family Forum 5 (2015) 141-160.

Makara-Studzińska, M. et al., "Lęk i depresja u kobiet leczonych z powodu niepłodności," Przegląd Menopauzalny 6 (2010) 414-418.

Miernik, B., "Mężczyzna wobec niepowodzeń prokreacyjnych. Psychopedagogiczne aspekty doświadczania przez mężczyzn trudności w prokreacji," Kwartalnik Naukowy Fides et Ratio 39/3 (2019) 94-106. 


\section{JACEK GOLEŃ}

Orzeszyna, J., Teologiczno-moralny aspekt niepłodności w małżeństwie (Kraków: Wydawnictwo Naukowe Papieskiej Akademii Teologicznej 2005).

Steger, M.F. et al., "The Meaning in Life Questionnaire: Assessing the Presence of and Search for Meaning in Life," Journal of Counseling Psychology 53/1 (2006) 80-93.

Waroński, W., "Niepłodność," Ginekologia (ed. R. Klimek) (Warszawa: Państwowy Zakład Wydawnictw Lekarskich 1982) 400-401.

Zaleski, Z., “Zgodność w uznawaniu wartości a zadowolenie z małżeństwa," Roczniki Filozoficzne 29/4 (1981) 163-173. 